\title{
Vizcacha's Influence on Vegetation and Soil in a Wetland of Argentina
}

\author{
Santiago M. Arias, Rubén D. Quintana, and Marcela Cagnoni \\ Authors are researchers in the Laboratorio de Ecología Ambiental y Regional, Departamento de Ecología, Genética y Evolución, \\ FCEyN, Universidad de Buenos Aires, Ciudad Universitaria, Pabellón II, C1428 EHA Buenos Aires, Argentina.
}

\begin{abstract}
We examined the influence of the plains vizcacha (Lagostomus maximus) on the vegetation structure and the characteristics of soil in a wet grassland area of Argentina. This rodent lives in social groups that share a communal burrow system that is occupied for several generations. The areas in which the vizcacha live and feed are strongly affected by grazing, trampling, and soil removal, exhibiting extensive biopedturbation. To evaluate these effects, we carried out a vegetation survey, along areas extending outward from active vizcacheras, analyzing abundance, plant diversity, vegetation cover, and biomass. We also established soil properties, analyzing physical and chemical variables from the center of the colonies to the grassland matrix. Our results show that vizcachas have indeed affected vegetation, diminishing plant cover and grass biomass in their grazing areas. Vegetation in both areas without animal activity and those of intense grazing was dominated by a few characteristic species. We verified the hypothesis of greatest diversity in areas of moderate disturbance. Perturbed areas had higher cation exchange capacity and electric conductivity and higher clay and sodium contents than the other areas. The rodents' activity introduces a recurrent disturbance factor to the landscape of this region, the outcome of which is the alteration of both the composition and structure of the botanical communities, and some soil properties, scaled in gradients of decreasing effect from the center of a colony to the periphery.
\end{abstract}

\section{Resumen}

Evaluamos la influencia de la vizcacha (Lagostomus maximus) en la estructura de la vegetación y las características del suelo en un pastizal húmedo de Argentina. Este roedor vive en grupos sociales compartiendo sistemas de cuevas que pueden estar ocupados durante varias generaciones. Las áreas bajo influencia directa de las vizcachas son intensamente afectadas por el pastoreo, el pisoteo y la remoción del suelo, exhibiendo una gran biopedopertubación. A fin de evaluar este efecto, se llevó a cabo una caracterización de la vegetación en un gradiente de actividad decreciente, a través del análisis de la abundancia, diversidad específica de la vegetación, cobertura y biomasa vegetal. Al mismo tiempo, las propiedades de los suelos fueron determinadas a través del análisis de variables físicas y químicas desde el centro de las colonias hasta la matriz de pastizal. Los resultados muestran que las vizcachas afectaron la vegetación, produciendo una disminución en la cobertura vegetal y en la biomasa de gramíneas en el área de alta actividad de pastoreo. Además, tanto la vegetación de las áreas sin actividad como las de alta actividad estuvieron dominadas por unas pocas especies características. Verificamos la hipótesis de máxima diversidad en las áreas de disturbio intermedio. Las zonas donde existe biopedoperturbación presentaron una mayor capacidad de intercambio catiónico y conductividad eléctrica, mayor contenido de $\mathrm{Na}^{+}$y arcilla respecto a las otras. La actividad de este roedor introduce un factor de disturbio recurrente al paisaje de esta región, cuyo resultado es la alteración de tanto la composición y estructura de las comunidades vegetales y de algunas propiedades del suelo en un gradiente de impacto decreciente desde el centro de las colonias a la periferia.

Key Words: biopedturbation, burrowing mammals, disturbance, Paraná River delta, plant-animal interactions

\section{INTRODUCTION}

Disturbance within an ecosystem can modify its functional and structural properties, producing recognizable patches in the landscape (White and Picket 1985). Herbivores play a key role in shaping landscape structure and function by altering the

This research project was financed by grants PICT 4503 from the Agencia Nacional para la Promoción Científica y Tecnológica and TX-904 from Universidad de Buenos Aires Ciencia y Técnica.

Correspondence: Dr. Santiago Arias, Laboratorio de Ecología Regional. Facultad de Ciencias Exactas y Waturales, PAB2 Ciudad Universitaria, C1428 EHA, Buenos Aires, Argentina.Email: santiagoarias@Argentina.com

Manuscript received 28 February 2003; manuscript accepted 20 August 2004. species composition of the botanical communities, controlling the flow of nutrients and provoking physical changes in the environment (Jones et al. 1994; Chapin et al. 1997). The outcome of this interaction is a function of the duration and intensity of the herbivore activity, the existing species of plants and herbivores, the soil nutrient status, and weather variations (Huntly 1991).

Burrowing mammals can cause long-term changes when they have high population density and occupy the same site for generations (Lawton 1994; Branch et al. 1999; Whitford and Kay 1999), either through direct plant clipping or by burrowing (biopedturbation: soil disturbance by animals). Burrowing causes soil removal and mixing and the addition of feces and plant matter, leading to changes in the nutrient availability, 
chemical composition, and structure of the soil (Inouye et al. 1987; Malizia et al. 2000), and hydrology (Coppock et al. 1983). Because biopedturbation affects different processes in the ecosystem (Coppock et al. 1983; Whicker and Detling 1988), it must be considered a key factor when analyzing ecosystem function (Whitford and Kay 1999).

As a consequence of soil disturbance, both plant species abundance and spaciotemporal aspects of the vegetation succession are affected (Archer et al. 1987; Inouye et al. 1987). Thus, burrowing mammals play a substantial role in shaping landscape structure (Whicker and Detling 1988; Branch et al. 1996).

The plains vizcacha (Lagostomus maximus) is a rodent herbivore endemic to South America, dwelling primarily in the semiarid scrub and grasslands from Bolivia and Paraguay to the center of Argentina. Similar in ecology and social behavior to black-tailed prairie dogs (Cynomys ludovicianus; Branch et al. 1996), these rodents live in communal burrow systems called "vizcacheras" ( 10-30 individuals), which are occupied by several generations (Llanos and Crespo 1952). Each vizcachera comprises numerous burrows spaced a few centimeters to several meters apart (Jackson et al. 1996) and typically covering an average area of $30 \mathrm{~m}^{2}$. Intensive selective grazing of the vizcachas in the area surrounding the colonies affects the botanical communities, resulting in a species change and an increase of bare ground (Giulietti and Jackson 1986; Puig et al. 1998; Branch et al. 1999).

Although vizcachas are distributed about central and northern Argentina, most descriptions of their effects are restricted to arid and semiarid environments (Kufner and Chambouleyron 1993; Branch et al. 1996; Branch et al. 2002). Until now, little information has been collected on these effects in wet grasslands, where agriculture and cattle are the main economic activities. Because of their effect on the environment, vizcacha populations often come into conflict with these economic activities.

The goal of this study was to test the hypothesis that 1) vizcacha activities increase spatial heterogeneity at the landscape level by promoting changes in the soil and vegetation structure, leading to higher diversity; 2) disturbance at moderate levels results in greater diversity of vegetation species; and 3) biopedturbation by vizcachas alters soil properties.

\section{MATERIALS AND METHODS}

Research was conducted on the Don José Ranch (1 500 ha; lat $33^{\circ} 27^{\prime} \mathrm{S}$, long $\left.58^{\circ} 48^{\prime} \mathrm{W}\right), 6 \mathrm{~km}$ north of Ceibas, Department of Gualeguaychú, Entre Ríos Province, Argentina. This ranch is situated in one of the 11 wetland landscape units identified for the Paraná River delta region. The landscape pattern corresponds to plains with a savanna physiognomy of grasses and patches of xerophytic black mesquite (Prosopis nigra Griseb.) and cavenia acacia (Acacia caven (Mol.) Mol.) forest. The area is also crisscrossed by small lentic streams covered with floating and rooted aquatic plants (Malvárez 1997).

Mean annual rainfall is $978 \mathrm{~mm}$, and temperature averages $17.4^{\circ} \mathrm{C}$ (Servicio Meteorológico Nacional 1980). Unlike its neighboring areas, it is free from the periodic floods of the Paraná River. Although it only receives water from rainfall, large areas are waterlogged because of the minimum slope of the land and the types of soils (Malvárez 1997). Soils are a clayey, sodic horizon close to the surface (Baumann 1999). The sodic clays hamper water penetration because they swell when wet, creating a layer that effectively is impermeable (Buol et al. 1989).

Extensive cattle ranching, hunting of wildlife species for food and trade, and exploitation of black mesquite trees for lumber are the main human activities in this region.

To assess the effect of vizcachas on vegetation structure and soil, we selected 6 active vizcacha colonies, surveying their activities either by direct observation or by means of their spoors (feces and footprints). To avoid overlap with areas frequented by vizcachas from other colonies, the studied vizcacheras were located farther than $200 \mathrm{~m}$ from each other. This distance effectively eliminated overlapping because preliminary observations indicated that the individuals of any one colony seldom wandered $>50 \mathrm{~m}$ from the burrows. At each vizcachera, we identified 4 concentric areas defined according to their radial distance to the center as a measure for the grazing activities of the rodent: a central area $(\mathrm{C})$, occupied by the vizcachera; a high-activity area (HA, 1-10 m); a medium- to low-activity area (MLA, $10-50 \mathrm{~m})$; and a no-activity area (NA, $>50 \mathrm{~m}$ ).

This partitioning was made on the basis of signs observed in the field, such as evidence of digging and dust baths (HA), feces and footprints (HA and MLA), or lack these signs (NA). Areas showing no activity were considered control plots.

The experimental design was a randomized complete block, 6 blocks represented by each vizcachera, and treatments were the distance to the center of the vizcachera, represented by the 4 areas (C, HA, MLA NA). On each of these areas, we determined plant composition, species abundance, and plant cover in 4 quadrats $(1 \times 1 \mathrm{~m})$, which is the recommended area for herbaceous plants (Mueller-Dombois and Ellemberg 1974). Each quadrat was randomly placed in each area with the use of the modified Braun-Blanquet abundance-cover scale (Mueller-Dombois and Ellemberg 1974). Then we harvested vegetal biomass within a quadrat $(0.60 \times 0.60 \mathrm{~m})$ in each of the chosen plots. This plot size was determined from previous sampling in a similar area (R. Vicari, personal communication). This biomass was oven dried at $60^{\circ} \mathrm{C}$ to a constant weight and then weighed. For the vegetation sampling, we avoided the area of highest vizcacha activity (hub of vizcacheras, C) because they present bare ground with only traces of vegetation.

To determine the influence on soil surface characteristics, soil samples were collected, discarding any vegetation and roots present, to a depth of $20 \mathrm{~cm}$ and oven dried at $40^{\circ} \mathrm{C}$ in each of the 4 activity areas (C, HA, MLA, and NA). These samples were then analyzed at the Laboratorio de Edafología de la Universidad Nacional del Comahue according to the methodology described by the US Department of Agriculture (USDA 1996), determining $\mathrm{pH}$ in distilled water, mixed 1:1 with dry soil. Electrical conductivity was calculated as the conductivity of water extracted from saturated paste. Cation exchange capacity was determined by ammonium acetate, $\mathrm{pH} 7$, and extractable bases $\left(\mathrm{Na}^{+}, \mathrm{K}^{+}, \mathrm{Ca}^{2+}, \mathrm{Mg}^{2+}\right)$ were extracted with ammonium acetate buffered at $\mathrm{pH} 7$. Organic matter was calculated by the Walkley and Black method (USDA 1996). Nitrogen content was calculated by combusting a soil sample at high temperature and measuring the $\mathrm{N}_{2}$ by thermal conductivity detection. Texture (percentage of sand, silt, and clay) was calculated by the hydrometric method. 
Table 1. Values of Hutcheson's test between diversity values and Student Newman Keuls test $(q)$ between the different activity areas for total species (R) and grass richness (RG) and for plant cover: bare ground $(B G)$, biomass of grasses $(G)$, and standing dead grasses $(D G){ }^{1}$

\begin{tabular}{|c|c|c|c|c|c|c|c|}
\hline \multirow[b]{2}{*}{ Comparison $^{2}$} & \multirow{2}{*}{$\begin{array}{l}\text { Hutcheson's } \\
\text { test }\end{array}$} & \multicolumn{6}{|c|}{ Student Newman Keuls test $q$} \\
\hline & & $\mathrm{R}$ & $R G$ & Cover & $B G$ & G & $\mathrm{DG}$ \\
\hline HA-MLA & $7.467^{\star}$ & $3.34^{*}$ & $4.33^{*}$ & $3.71^{*}$ & $3.75^{\star}$ & $4.21^{*}$ & $5.19^{*}$ \\
\hline $\mathrm{HA}-\mathrm{NA}$ & $-4.28^{\star}$ & $3.89^{*}$ & $5.47^{*}$ & $5.71^{*}$ & $5.52^{*}$ & $4.67^{*}$ & $3.95^{*}$ \\
\hline MLA-NA & $-4.66^{*}$ & 0.55 & 1.13 & 2 & 1.77 & 0.46 & 1.24 \\
\hline
\end{tabular}

Cattle grazing $\left(0.7\right.$ cows ha $\left.{ }^{-1}\right)$ on this ranch was continuous during the study period all along the area, including vizcacha foraging zones. Therefore, we consider that this disturbance had a similar effect on all the area.

Diversity of vegetation species was calculated with the Shannon-Weaver diversity index $\left(H^{\prime}\right)$, and the resulting values were statistically compared by means of the Hutcheson test (Zar 1996). Evenness was calculated by the Brillouin index ( $J^{\prime}$, Zar 1996).

To avoid pseudoreplication when analyzing plant abundance and cover, the data from each of the 4 surveyed quadrats were averaged after detailed comparison. We did not analyze cover of individual species because only 4 plant species averaged higher than $10 \%$ cover at any distance from the vizcachera. We grouped plant species by life history for biomass analysis because of the large number of species encountered in the study areas and the low weight of most individual species. Plant samples were classified in 4 categories: grasses $(G)$, forbs $(F)$, standing dead grass (DG), and standing dead forbs (DF).

Differences were analyzed by analysis of variance (ANOVA; Zar 1996). The independent variable was increasing distance from the vizcachera, and the dependent variables were plant cover and bare ground, biomass groups and species richness, and the edaphic variables. Vizcacheras (Viz) were considered as a block, and the ANOVA was used to check for differences between activity areas (Act). When differences in variables were found along the activity gradient, we carried out the Student Newman Keuls test for multiple comparisons (Zar 1996).

\section{RESULTS}

A total of 61 plant species ( 32 forbs and 29 grasses) was recorded in all samples taken during this study. Grasses constituted $74.6 \%$ and forbs $25.4 \%$ in dry weight of all sampled vegetation. On the $\mathrm{HA}$ area, grass Paspalum vaginatum Swartz and forbs Euphorbia spathulata Lam., creeping lippia (Phyla canescens (HBK) Greene), and dichondra (Dichondra microcalyx (Hallier) Fabris.) predominated. In the MLA zone, the proportion of grasses increased, mainly $P$. vaginatum, Panicum milioides Nees., Setaria geniculata (Lam.) Beauv., Chloris sesquiflora Burk., and the forb dichondra. Similarly, the NA areas were characterized by grasses $P$. milioides, S. geniculata, C. sesquiflora, Luziola peruviana Gmel., and P. vaginatum.

According to the Shannon index, $\quad\left(H_{\mathrm{HA}}^{\prime}=2.37\right.$; $\left.H_{\mathrm{MLA}}^{\prime}=2.88 ; H_{\mathrm{NA}}^{\prime}=2.64\right)$; MLA zones were more diverse than NA and HA (Table 1), whereas species diversity in HA
Table 2. Randomized block design analysis of variance results between the different activity areas (Act) at 6 vizcacheras (Viz) for species richness $(R)$, grass richness (GR), forb richness (FR), plant cover (PC), bare ground $(B G)$, and biomass categories: grasses $(G)$, forbs $(F)$, standing dead grass (DG), and standing dead forbs (SDF). df indicates degrees of freedom.

\begin{tabular}{|c|c|c|c|}
\hline & Source of variation & df & $P$ \\
\hline \multirow[t]{3}{*}{$\mathrm{R}$} & Act & 2 & 0.042 \\
\hline & Viz & 5 & 0.371 \\
\hline & Total & 17 & \\
\hline \multirow[t]{3}{*}{ GR } & Act & 2 & 0.007 \\
\hline & Viz & 5 & 0.596 \\
\hline & Total & 17 & \\
\hline \multirow[t]{3}{*}{ FR } & Act & 2 & 0.827 \\
\hline & Viz & 5 & 0.035 \\
\hline & Total & 17 & \\
\hline \multirow[t]{3}{*}{$\mathrm{PC}$} & Act & 2 & 0.007 \\
\hline & Viz & 5 & 0.560 \\
\hline & Total & 17 & \\
\hline \multirow[t]{3}{*}{$B G$} & Act & 2 & 0.009 \\
\hline & Viz & 5 & 0.542 \\
\hline & Total & 17 & \\
\hline \multirow[t]{3}{*}{ G } & Act & 2 & 0.015 \\
\hline & Viz & 5 & 0.109 \\
\hline & Total & 17 & \\
\hline \multirow[t]{3}{*}{$D G$} & Act & 2 & 0.011 \\
\hline & Viz & 5 & 0.058 \\
\hline & Total & 17 & \\
\hline \multirow[t]{3}{*}{$\mathrm{F}$} & Act & 2 & 0.834 \\
\hline & Viz & 5 & 0.007 \\
\hline & Total & 17 & \\
\hline \multirow[t]{3}{*}{ DF } & Act & 2 & 0.190 \\
\hline & Viz & 5 & 0.552 \\
\hline & Total & 17 & \\
\hline
\end{tabular}

areas turned out to be lower than the NA areas. Evenness was higher in MLA areas $\left(J_{\mathrm{HA}}^{\prime}=0.66 ; J_{\mathrm{MLA}}^{\prime}=0.74 ; J_{\mathrm{NA}}^{\prime}=0.68\right)$.

Mean species richness showed significant differences throughout the gradient (Table 2), but not among vizcacheras. The HA zones showed lower species richness (Fig. 1; Table 1), whereas there were no differences between the MLA and NA

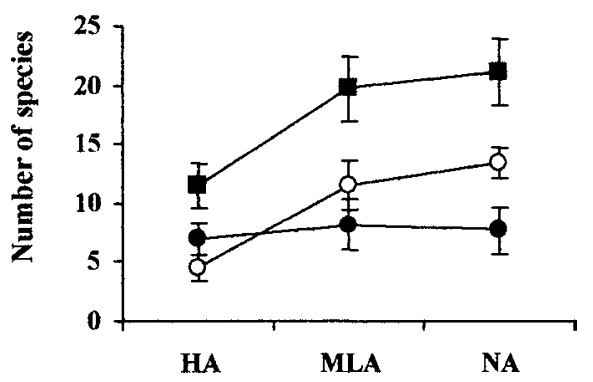

Figure 1. Mean number ( $\pm \mathrm{SE} ; n=6$ ) of total species $(\boldsymbol{\square})$, grasses $(\mathrm{O})$, and forbs $(\bigcirc)$ recorded in $4 \mathrm{~m}^{2}$ for each high- $(\mathrm{HA})$, medium- to low- (MLA), and no-activity (NA) area at 6 vizcacheras measured in December 1999 in a wet grassland of Entre Ríos Province. 


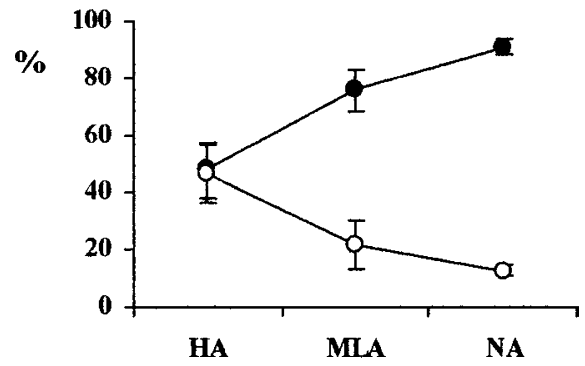

Figure 2. Percent cover $( \pm \mathrm{SE})$ of plants $(\mathbf{O})$ and bare ground $(O)$ in areas of high (HA), medium to low (MLA), and no activity (NA). Each dot represents the mean cover for each activity area at 6 vizcacheras from a mean of 4 plots per area.

zones. The same results were found for grass richness (Fig. 1; Tables 1 and 2), whereas forbs showed differences among vizcacheras (Table 2) but not among activity zones, indicating that variation in forb richness along the activity gradient was different at the different colonies (Fig. 1).

Plant cover changed with increasing distance from the vizcachera (Tables 1 and 2), with an increase toward the periphery (Fig. 2). Plant cover was much lower at HA areas compared with MLA and NA areas, whereas no differences were observed between them (Table 1). Bare ground also showed significant differences along the gradient when the areas were compared (Tables 1 and 2). When comparing vizcacheras, we found no significant differences in either vegetation or bare ground (Table 2; Fig. 2).

Similarly, both the grass biomass and the standing dead grass showed significant differences along the gradient, but not among vizcacheras (Table 2; Fig. 3). Biomass of grass and standing dead grass was lower in HA areas than in MLA and NA areas but was similar when comparing MLA and NA areas (Table 1; Fig. 3).

There were differences in forb biomass among vizcacheras (Table 2), indicating a different biomass variation along the gradient among colonies. However, there were no differences between the areas with and without vizcacha activity. The biomass of standing dead forbs was similar in all activity areas.

As for the edaphic variables, electric conductivity, cation exchange capacity, $\mathrm{Na}^{+}$, and clay content differed between the activity areas (Table 3; Fig. 4). Both electrical conductivity, cation exchange capacity, and $\mathrm{Na}^{+}$were significantly higher in areas in which soil was disturbed by digging $(\mathrm{C})$ than in the other activity areas (Table 4). Clay content (Fig. 5) was higher in the center than in the NA zones but was only slightly

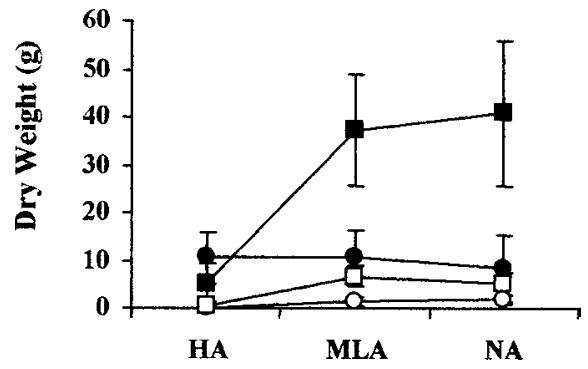

Figure 3. Dry weight ( $\mathrm{g} \pm \mathrm{SE}$ ) of grass biomass $(\boldsymbol{\square})$, standing dead grasses $(\square)$, forbs $(\mathbf{O})$, and standing dead forbs $(O)$ in areas of high (HA), medium to low (MLA), and no activity (NA) around 6 vizcacheras.
Table 3. Randomized block design analysis of variance results between the different activity areas (Act) at 6 vizcacheras (Viz) for edaphic variables. $^{1}$

\begin{tabular}{|c|c|c|c|}
\hline & Source of variation & df & $P$ \\
\hline \multirow[t]{3}{*}{ pH } & Act & 3 & 0.243 \\
\hline & Viz & 5 & 0.362 \\
\hline & Total & 23 & \\
\hline \multirow[t]{3}{*}{ EC } & Act & 3 & 0.000 \\
\hline & Viz & 5 & 0.284 \\
\hline & Total & 23 & \\
\hline \multirow[t]{3}{*}{$\mathrm{Na}^{+}$} & Act & 3 & 0.000 \\
\hline & Viz & 5 & 0.027 \\
\hline & Total & 23 & \\
\hline \multirow[t]{3}{*}{ CEC } & Act & 3 & 0.002 \\
\hline & Viz & 5 & 0.020 \\
\hline & Total & 23 & \\
\hline \multirow[t]{3}{*}{ OM } & Act & 3 & 0.442 \\
\hline & Viz & 5 & 0.297 \\
\hline & Total & 23 & \\
\hline \multirow[t]{3}{*}{$\mathrm{N}$} & Act & 3 & 0.513 \\
\hline & Viz & 5 & 0.256 \\
\hline & Total & 23 & \\
\hline \multirow[t]{3}{*}{$\mathrm{Ca}^{2+}$} & Act & 3 & 0.725 \\
\hline & Viz & 2 & 0.566 \\
\hline & Total & 11 & \\
\hline \multirow[t]{3}{*}{$\mathrm{Mg}^{2+}$} & Act & 3 & 0.703 \\
\hline & Viz & 2 & 0.453 \\
\hline & Total & 11 & \\
\hline \multirow[t]{3}{*}{ Clay } & Act & 3 & 0.037 \\
\hline & Viz & 5 & 0.227 \\
\hline & Total & 23 & \\
\hline \multirow[t]{3}{*}{ Silt } & Act & 3 & 0.805 \\
\hline & Viz & 5 & 0.357 \\
\hline & Total & 23 & \\
\hline \multirow[t]{3}{*}{ Sand } & Act & 3 & 0.636 \\
\hline & Viz & 5 & 0.559 \\
\hline & Total & 23 & \\
\hline
\end{tabular}

${ }^{1} \mathrm{EC}$ indicates electrical conductivity; $\mathrm{Na}^{+}$, sodium; $\mathrm{CEC}$, cation exchange capacity; $\mathrm{OM}$ organic matter; $\mathrm{N}$, nitrogen; $\mathrm{Ca}^{2+}$, calcium; $\mathrm{Mg}^{2+}$, magnesium; $\mathrm{df}$, degrees of freedom.

elevated in the HA areas and MLA areas. Cation exchange capacity and $\mathrm{Na}^{+}$also showed significant differences among colonies (Table 3; Figs. 4 and 5).

\section{DISCUSSION}

The biotic and abiotic attributes analyzed have shown differences in the effect of vizcacha activity. As with other burrowing mammals (Carlson and White 1988; Swihart 1991; Guo 1996; Weltzin et al. 1997; Kinlaw 1999; Malizia et al. 2000), these rodents' activity had a marked effect on the plant communities and soil; an effect that correlates with the intensity of this activity. As a result of vizcacha activity, species richness, plant composition and cover, diversity, and aboveground herbaceous biomass changed substantially. Burrowing activity produced 

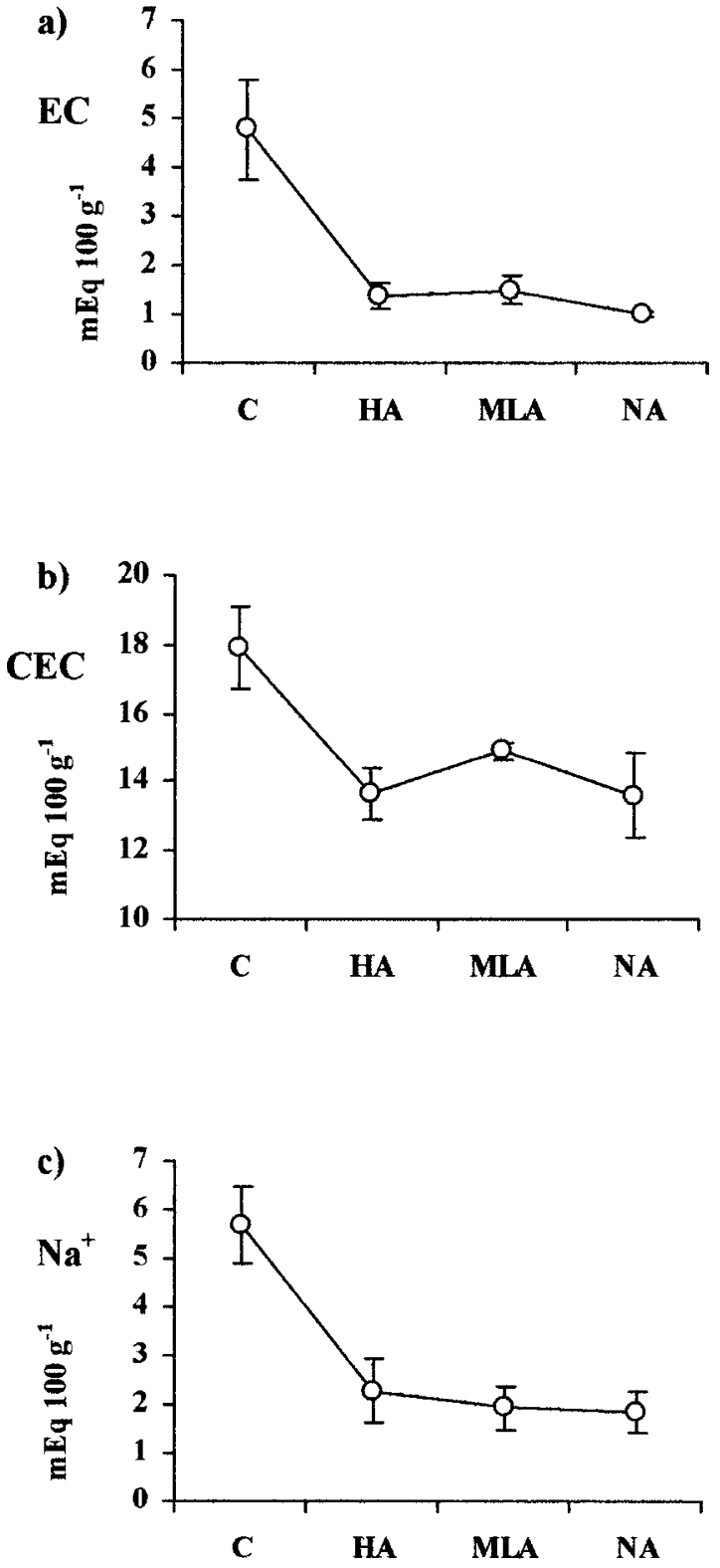

Figure 4. Mean soil surface variables $( \pm \mathrm{SE})$ along the activity gradient at 6 vizcacheras. A, EC indicates electric conductivity. B, CEC indicates cation exchange capacity (mEq $\left.[100 \mathrm{~g}]^{-1}\right)$. C, Na $\left(\mathrm{mEq}[100 \mathrm{~g}]^{-1}\right)$ at the center of each vizcachera $(C)$ and areas with high $(\mathrm{HA})$, medium to low (MLA), and null activity (NA).

significant changes in the chemical and physical properties of the soil in the center of the colony.

As for our hypothesis, the structure of vegetation was different in the 3 activity areas studied. Plant cover in the areas of intense grazing decreased significantly, causing alterations in the structure of vegetation: a community dominated by grasses in the grassland matrix became mainly forbs, with large percentages of bare ground in the areas of most intensive grazing. A decrease in grass biomass around the colonies and an increase of bare ground areas might be caused by the grazing habits and related activities of this rodent, whose diet is composed mainly of graminoid species (Giullieti and Jackson 1986; Puig et al. 1998; Pereira et al. 2003). Similar results were
Table 4. Student Newman Keuls test $(q)^{1}$ between the center of each vizcachera (C), areas of high (HA), medium to low (MLA), and no activity (NA) for soil variables. ${ }^{2}$

\begin{tabular}{lllll}
\hline Comparison & $q \mathrm{EC}$ & $q \mathrm{Na}^{+}$ & $q \mathrm{CEC}$ & $q$ Clay \\
\hline C-HA & $6.49^{*}$ & $7.37^{*}$ & $5.86^{*}$ & 3.61 \\
C-MLA & $6.27^{*}$ & $8.12^{*}$ & $4.15^{\star}$ & 2.8 \\
C-NA & $7.20^{*}$ & $8.34^{*}$ & $5.95^{\star}$ & $4.39^{*}$ \\
HA-MLA & 0.23 & 0.75 & 1.71 & 0.82 \\
HA-NA & 0.71 & 0.97 & 0.09 & 0.77 \\
MLA-NA & 0.93 & 0.22 & 1.8 & 1.59 \\
\hline${ }^{1} P<0.05$. & \multicolumn{4}{l}{} \\
${ }^{2} \mathrm{EC}$ indicates electrical conductivity; $\mathrm{Na}^{+}$, sodium; and CEC, cation exchange capacity.
\end{tabular}

found in intensive grazing situations for vizcachas in more arid habitats (Branch et al. 1996, 1999; Villarreal et al. 2001). As a result, vizcachas produce open patches of bare ground dominated by forb species surrounding the burrow systems. Forbs have higher nutrient content (e.g. of nitrogen and phosphorus) and produce higher quality litter than grasses (Branch et al. 2002); therefore, vizcacha activity increases nutrient availability in the environment.

In turn, the decreasing disturbance gradient from the vizcacheras toward the periphery provides a test for the disturbance hypothesis that predicts intermediate levels of disturbance in a greater number of species (Connell 1978). Our results support this hypothesis: we found the highest diversity of plant species in the MLA areas. In areas of high grazing and circulation, where we found the lowest diversity values, the rate of grazing reduced species richness to the point where only a few "fugitive" species managed to survive and reproduce, allowing the establishment of species that are less frequent in other areas (e.g. E. spathulata and creeping lippia). This establishment resulted in a substitution of the dominant species close to the colonies. Lower diversity in the NA areas is a result of the domination of the area by a few species typical of the grassland matrix (P. milioides, S. geniculata, and Carex bonariensis [Desf]; Malvárez 1997), which lowers the diversity index value because of lower evenness.

Guo (1996) has pointed out that, with an activity gradient from highly disturbed areas to those relatively free of disturbance, the intermediate disturbed zone can be considered an ecotone in which disturbance-resistant species coexist with

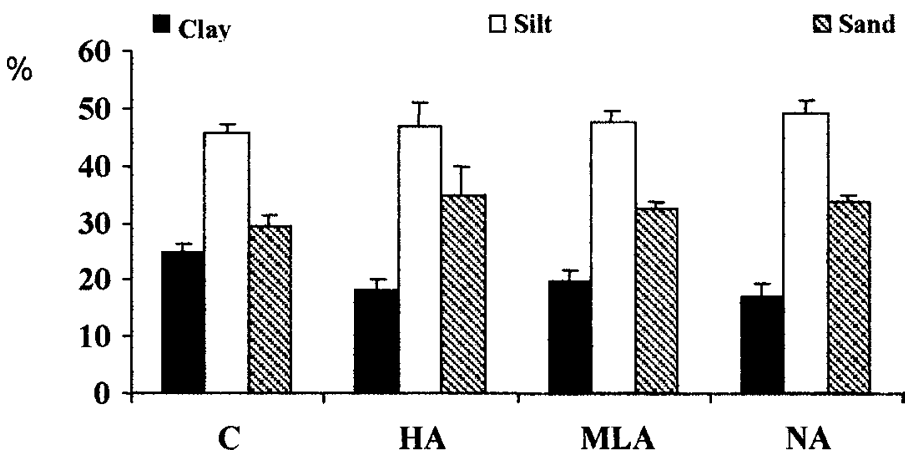

Figure 5. Mean percent $( \pm \mathrm{SE}$ ) soil surface composition (clay, silt, and sand) at the center of each vizcachera (C) and in areas with high (HA), medium to low (MLA), and null activity (NA). 
those typical of the matrix. Our survey showed that species at MLA areas are present also in other areas: E. spathulata and creeping lippia were found both at HA and MLA zones, although they were less abundant in the latter. P. milioides, S. geniculata, and C. sesquiflora, in turn, were found in both MLA and NA zones, but were rare to absent in the HA areas.

Although our work did not analyze the mechanism that produced alterations in plant communities subject to intensive grazing, some authors (Briske 1991; Briske and Richards 1994) have pointed out that the substitution of plant species caused by herbivores might relate to the species' ability to tolerate or avoid recurrent defoliation. The dichondra was found in all the activity areas in similar proportion. However, field observations showed morphologic variations in its growth within HA zones, in which it acquired dwarf habits (commonly, $<1 \mathrm{~cm}$ ), whereas in the other 2 zones, it grew upright (in general, to $>2 \mathrm{~cm}$ ). By means of this antipredatory strategy in intensive grazing areas, they could escape defoliation (Crawley 1983). The same strategy was found in the case of creeping lippia in HA and MLA zones.

The most obvious effect of burrowing mammals on soils is the vizcachera itself, observable as a mound of loose accumulated dirt under which run the complex of tunnels and galleries. According to several authors (Inouye et al. 1987; Huntly and Reichman 1994; Whitford and Kay 1999; Malizia et al. 2000), burrows in the landscape have an effect at diverse scales on the geomorphology, hydrology, soil dynamics, patterns of vegetation, and diversity of animal species. The results of our survey support this hypothesis because we observed alterations in some of the chemical components of the soil and its texture.

Thus, the higher $\mathrm{Na}^{+}$content, much more concentrated at the excavated spots than where the soil was not turned over by the vizcachas, might be explained by the marine origin of the sediments that compose the original matter of the soil in that area (Malvárez 1997), or it might be because of the presence of a natric horizon containing sodium clays under the surface (Baumann 1999). By excavation, the lower horizons with high sodium content are brought to the surface and mixed with the higher horizons, thus producing a cation increment on the ground level and an alteration of texture. According to Abaturov (1972), biopedturbation might be the most important mechanism acting on the system pumping soluble nutrients from the lower horizons of the soil $(10-200 \mathrm{~cm})$ toward the surface in some environments.

On the other hand, soil electric conductivity was higher in the central areas $(\mathrm{C})$. This situation might be a consequence of the high sodium content found on the surface. The cation exchange capacity increment on the colonies' surface could be a result of higher clay content; clays are known to increase the ability of the soil to hold metallic cations (Buol et al. 1989).

The rest of the chemical variables analyzed show no significant differences among all 3 activity areas and the digging zone. Although several studies claim that $\mathrm{N}$ concentration, like that of $\mathrm{H}^{+}$, should increase in burrowing areas through the accumulation of feces and urine and the removal of vegetation by water infiltration variations because of the microtopography of the burrow mounds (for a review, see Whitford and Kay 1999), this survey did not record any change in these variables or in the content of organic matter, although vizcachas excrete inside the burrows and accumulate cattle feces and decaying animals in the same spots. On the contrary, the $\mathrm{pH}$ showed a trend to increase in the removed areas (Fig. 4). This slight difference found among variables might have been caused by more rainfall and waterlogging in 1998, coincident with an El Niño event, than in previous years (Servicio Meteorológico Nacional 1980). This situation might cause an increase in the leaching rate of soil nutrients toward the lower horizons, thereby obscuring the effects of excavation, because the rate of leaching is higher in excavated areas than in the surrounding soils (Whitford and Kay 1999), which might help this process.

Therefore, vizcachas might cause changes in the availability of soil nutrients and minerals, although their effect on the system will depend on the edaphic peculiarities. At the surveyed area, the "digger" role might favor plant species resistant to high sodium concentration and, at the same time, species with strategies to avoid recurrent defoliation or that are unpalatable to vizcachas.

The rodents' activity introduces a recurrent disturbance factor to the landscape of this region, the outcome of which is the alteration of both the composition and structure of the botanical communities and some soil properties, scaled in gradients of decreasing effect from the center of a colony to the periphery.

Vizcacha activity should be kept in mind when establishing management plans that consider traditional productive activities and conservation of wetland biodiversity.

\section{ACKNOWLEDGMENTS}

The authors thank Mr I. Schojett for allowing the study to be conducted on his ranch; N. Madanes, P. Bertolini, F. Gagliardi, P. Pratolongo, K. D'Stefano, and M. Srur for their field support; G. Cueto for his valuable help with statistics; L. Azcoaga for her invaluable help with the English translation; and anonymous reviewers for constructive criticism. Identification of botanical specimens was performed by Dr Patricia Hoc from the Laboratory of Vascular Plants at Facultad de Ciencias Exactas y Naturales, Universidad de Buenos Aires.

\section{LITERATURE CITED}

Abaturov, B. D. 1972. The role of burrowing animals en the transport of mineral substances in the soil. Pedobiologia 12:261-266.

Archer, S., M. G. Garrett, and J. K. Detling. 1987. Rates of vegetation change associated with prairie dog (Cynomys ludovicianus) grazing in North American mixed grass prairie. Vegetatio 72:159-166.

Baumann, V. 1999. Caracterización geomorfológica y distribución de los suelos en el sudeste de la provincia de Entre Ríos. Buenos Aires [Tesis de Licenciatura en Ciencias Geológicas]. Buenos Aires, Argentina: Univ. of Buenos Aires.

Branch, L., J. L. HierRo, and D. Villareal. 1999. Patterns of plant species diversity following local extinction of the plains vizcacha in semi arid scrub. Journal of Arid Environments 41:173-182.

Branch, L., D. Villareal, and M. Machicote. 2002. Conservation challenges of ecosystem engineers: case studies from grasslands and shrublands of North and South America. The Open Country 4(summer): 37-48.

Branch, L. D, J. Villareal, J. L. Hierro, and Y. K. Portier. 1996 Effects of local extinction of the Plains viscacha (Lagostomus maximus) on semi-arid scrub. Oecologia 106:389-399.

BRISKE, D. D. 1991. Developmental morphology and physiology of grasses. In R. K. Heitschmidt and J. W. Stuth [eds.]. Grazing management: An ecological perspective. Portland, OR: Timber Press. p. 85-108.

BRISKE, D. D., AND J. H. RICHARDS. 1994. Physiological responses of individual plant to grazing: current status and ecological significance. In: M. Vavra, W. A. 
Laycock, and R. D. Pieper [eds.]. Ecological implications of livestock herbivory in the West. Denver, C0: Society for Range Management. p. 147-176.

Buol, S., F. Hole, and R. McCraken. 1989. Soil genesis and classification. Iowa State University Press.

Carlson, D. C., and E. M. White. 1988. Variations in surface-layer color, texture, $\mathrm{pH}$, and phosphorus content across prairie dog mounds. Soil Science Society of America Journal 52:1758-1761.

Chapin, F. S., III, B. H. Walker, R. J. Hobbs, D. U. Hooper, J. H. Lawton, O. E. Sala, AND D. TILMAN. 1997. Biotic control over the functioning of ecosystems. Science 277:500-504.

ConnelL, J. H. 1978. Diversity in tropical rain forests and coral reefs. Science 199:1302-1310.

Coppock, D. L., J. K. Detling, J. E. ElLis, And M. I. Dyer. 1983. Plant-herbivore interactions in a North American mixed-grass prairie. I. Effects of black tailed prairie dogs on intraseasonal aboveground plant biomass and nutrient dynamics and plant species diversity. Oecologia 56:1-9.

Crawley, M. 1983. Herbivory. The dynamics of animal-plant interactions. Studies in ecology Volume 10. Berkeley and Los Angeles, CA: California Univ. Press.

Giulietti, J. D., AND J. E. Jackson. 1986. Composición anual de la dieta de la vizcacha (Lagostomus maximus) en pastizales naturales en la provincia de San Luis, Argentina. Revista Argentina de Producción Animal 6:229-237.

Guo, Q. 1996. Effects of bannertail kangaroo rat mounds on small-scale plant community structure. Oecologia 106:247-256.

HuntLy, N. J. 1991. Herbivores and the dynamics of communities and ecosystems. Annual Review of Ecology and Systematics 22:477-503.

Huntly, N. J., AND 0. J. Reichman. 1994. Effects of subterranean mammalian herbivores on vegetation. Journal of Mammalogy 75:852-859.

Inouye, R. S., N. J. Huntly, D. Tilman, and J. R. Tester. 1987. Pocket gophers (Geomys bursarius), vegetation and soil nitrogen along a successional sere in east central Minnesota. Oecología (Berlín) 75:291-295.

Jackson, J. E., L. C. Branch, and D. Villareal. 1996. Lagostomus maximus. Mammalian Species 543:1-6.

Jones, C. G., J. H. LaWton, and M. Shachak. 1994. Organisms as ecosystem engineers. Oikos 69:373-386.

KINLAW, A. 1999. A review of burrowing by semi-fossorial vertebrates in arid environments. Journal of Arid Environments 41:127-145.

Kufner, M. B., and M. B. Chambouleyron. 1993. Distribución de colonias de Lagostomus maximus maximus en relación a variables del hábitat y su impacto en el medio desértico del monte, Argentina. Doñana, Acta Vertebrata 20(1):81-87.
Lawton, J. H. 1994. What do species do in ecosystems? Oikos 71:367-374.

Llanos, A., AND J. CRESPo. 1952. Ecología de la vizcacha (Lagostomus maximus maximus Blainv.) en el nordeste de la provincia de Entre Ríos. Rev. Investigaciones Agrícolas 6:289-378.

Malizia, A. I., M. J. Kittlein, and C. Busch. 2000. Influence of the subterranean herbivorous rodent Ctenomys talarum on vegetation and soil. Zeitschrift für Säugetierkunde 65:172-182.

Malvárez, A. I. 1997. Plant communities of the Paraná River delta. Their relation with environmental factors and landscape patterns [Las comunidades vegetales del Delta del Río Paraná. Su relación con factores ambientales y patrones del paisaje] [thesis]. Buenos Aires, Argentina: Univ. of Buenos Aires.

Mueller-Dombois, D., and E. Ellemberg. 1974. Aims and methods of vegetation ecology. New York, NY: John Wiley and Sons.

Pereira, J., R. D. Quintana, and S. Monge. 2003. Diets of plains vizcacha, greater rhea and cattle in Argentina. Journal of Range Management 56:13-20.

Puig, S., F. Videla, M. Cona, S. Monge, and V. Roig. 1998. Diet of the vizcacha Lagostomus maximus (Rodentia, Chinchillidae), habitat preferences and food availability in Northern Patagonia, Argentina. Mammalia 62:191-204.

Servicio Meteorológico Nacional. 1980. Estadística climatológica. Serie B, No. 6. Buenos Aires, Argentina: Fuerza Aérea Argentina.

SwIHART, R. K. 1991. Influence of Marmota monax on vegetation in hayfields. Journal of Mammalogy 72:791-795.

[USDA] US DepartMent OF AgRICULtURE. 1996. Soil survey laboratory methods manual. Natural Resources Conservation Service Soil Survey Cent, SSIR 42.

Villareal, D., L. C. Branch, M. Mahicote and J. L. Hierro. 2001. Riqueza de especies en un gradiente de herbiboría de vizcachas (Lagostomus maximus Hollister). Rev. Fac. Agronomí. UNLPam 12:41-54.

Weltzin, F. J., S. L. Dowhower, and R. K. Heitschmidt. 1997. Prairie dog effects on plant community structure in southern mixed-grass prairie. The Southern Naturalist 42:251-258.

Whicker, A., And J. Detling. 1988. Ecological consequences of prairie dog disturbances. BioScience 38:778-778.

White, P. S., AND S. T. A. PICKet. 1985. Natural disturbance and patch dynamics: an introduction. In: S. T. A. Picket and P. S. White [eds.]. The ecology of natural disturbance and patch dynamics. Orlando, FL: Academic Press. p. 3-13.

Whitford, W. G., and F. R. Kay. 1999. Biopedturbation by mammals in deserts: a review. Journal of Arid Environments 41:203-230.

ZAR, J. 1996. Biostatistical analysis. 3rd ed. New Jersey: Prentice-Hall, Inc. 